\title{
Studies on $\boldsymbol{S}$-Adenosylmethionine-Magnesium Protoporphyrin Methyltransferase in Euglena gracilis Strain Z
}

\author{
By JEAN G. EBBON AND G. H. TAIT \\ Department of Chemical Pathology, St Mary's Hospital Medical School, London, W. 2
}

(Received 20 September 1968)

\begin{abstract}
1. An enzyme that methylates magnesium protoporphyrin was detected in extracts of light-grown and dark-grown cells of Euglena gracilis. The activity in light-grown cells is two to three times that in cells grown in the dark. 2. The activity is mainly located in the chloroplast fraction from light-grown cells and in proplastids in dark-grown cells. However, in cells grown either in the light or dark, about $15-20 \%$ is found in particle-free supernatant. 3. The chloroplast methylating enzyme was solubilized by the action of Tween 80 and partially purified. The properties were investigated. 4. From experiments in which etiolated cells were illuminated in the presence of inhibitors of chloroplast or cytoplasmic protein synthesis, it appears that the methylating enzyme is made on cytoplasmic ribosomes.
\end{abstract}

Tait \& Gibson (1961) and Gibson, Neuberger \& Tait (1963) reported that chromatophores from Rhodopseudomonas spheroides catalysed the formation of magnesium protoporphyrin monomethyl ester from magnesium protoporphyrin and $S$ adenosylmethionine. Some of the properties of the enzyme were listed, but attempts to purify it were unsuccessful as it was not possible to solubilize the chromatophore enzyme. In oxygen-grown cells of Rhodopseudomonas spheroides, which lack chromatophores and bacteriochlorophyll, the enzyme activity was found to be very low. Further work by Gorchein, Neuberger \& Tait (1967) showed that the activity of the enzyme in cells increased about 30-50-fold on adaptation from growth in oxygen in the dark to growth at low partial pressure of oxygen in the light or in the dark. An enzyme catalysing the methylation of magnesium protoporphyrin was detected in Zea mays by Radmer \& Bogorad (1967); the enzyme was found to be in chloroplasts.

In the present work the enzyme was found in Euglena gracilis. Activity is located both in chloroplasts and in the soluble fraction of the cell. The enzyme was extracted from chloroplasts with detergent and further purified; some of its properties are reported. The activity of the enzyme in Euglena gracilis grown under different conditions was investigated. Experiments with inhibitors suggest that the site of synthesis is on the cytoplasmic ribosomes, although most of the enzyme is found in chloroplasts.

\section{MATERIALS AND METHODS}

Chemicals. The reineckate of $S$-adenosyl-L- $\left[M e-{ }^{14} \mathrm{C}\right]$. methionine was prepared enzymically (Cantoni, 1957) and stored at $-20^{\circ}$. It was decomposed to $S$-adenosylmethionine by the method of Cantoni (1957). Tween 80 was obtained from Honeywill and Stein Ltd., London, W. 1.

Porphyrins. (a) Protoporphyrin. Protoporphyrin dimethyl ester was prepared as described by Grinstein (1947). Free protoporphyrin IX was prepared by acid hydrolysis of the dimethyl ester.

(b) Magnesium protoporphyrin. The preparation of magnesium protoporphyrin was carried out essentially as described by Baum, Burnham \& Plane (1964). Protoporphyrin IX dimethyl ester (350 mg.) was dissolved in dry pyridine $\left(60 \mathrm{ml}\right.$.) to which was added $\mathrm{Mg}\left(\mathrm{ClO}_{4}\right)_{2}(300 \mathrm{mg}$.). This mixture was autoclaved in a sealed tube at 18lb./in. ${ }^{2}$ for $2 \mathrm{hr}$. The solution was then diluted with $2 \mathrm{vol}$. of water and extracted three times with chloroform. The chloroform layer was washed several times with water. The solution was dried over anhydrous $\mathrm{Na}_{2} \mathrm{SO}_{4}$; it was filtered and evaporated to dryness. The residue was extracted with successive $10 \mathrm{ml}$. volumes of ether; the spectrum of each extract was measured with a recording spectrophotometer and extraction continued as long as a metalloporphyrin was being extracted. The extracts were pooled and evaporated to a small volume. An equal volume of light petroleum (b.p. $40-60^{\circ}$ ) was added and the solution allowed to stand overnight. The precipitate was removed by centrifuging, washed with light petroleum, dried in vacuo and stored at $-20^{\circ}$.

Magnesium protoporphyrin was prepared from the dimethyl ester by alkaline hydrolysis by the method of Granick (1948). The product was suspended in $0.5 \mathrm{M}$ potassium phosphate buffer, $\mathrm{pH} 7 \cdot 0$, and kept at $-20^{\circ}$. 
Organisms. Euglena gracilis strain $\mathrm{Z}$ were obtained from Professor G. E. Fogg, Department of Botany, Westfield College, London, N.W. 3; this strain came originally from Dr S. H. Hutner, Haskins Laboratories, New York, N.Y., U.S.A. Cells were grown either in the light or in darkness for 6 days at $24-28^{\circ}$ in a medium containing $0.5 \%$ peptone, $0.2 \%$ yeast extract and $1.5 \%$ glucose that had been sterilized by autoclaving at $10 \mathrm{lb}$./in. ${ }^{2}$ for $10 \mathrm{~min}$. Autotrophically grown cells were cultured, in the light, in the medium of Hutner, Bach \& Ross (1956) as modified by Eisenstadt \& Brawerman (1964). All manipulations before cell breakage, on dark-grown organisms, were carried out in a dim green light.

Preparation of extracts. Disrupted cells were fractionated by a modification and extension of the procedure described by Carell \& Kahn (1964) and their terminology for the subcellular fractions has been used. The cells were harvested by centrifuging at $13000 \mathrm{~g}$ for $10 \mathrm{~min}$. and were washed with 1 mu-potassium phosphate buffer, pH7.5. The cells were then suspended in MTN medium [0.5 M-mannitol-0.05 Mtris-HCl buffer ( $\mathrm{pH} 7.5)-0.01 \mathrm{M}-\mathrm{NaCl}-0.1 \mathrm{~mm}$-ascorbic acid] and crushed in the French pressure cell at $1500 \mathrm{lb}$./in. ${ }^{2}$. The suspension was centrifuged at $2000 \mathrm{~g}$ for $1 \mathrm{~min}$. (excluding acceleration and deceleration time). The supernatan f from this step was termed the 'cell-free homogenate' (S). This fraction was centrifuged at $3000 \mathrm{~g}$ for $10 \mathrm{~min}$. and the pellet was suspended in MTN medium and termed 'crude whole chloroplasts' $\left(F_{1} a\right)$. The supernatant was then centrifuged at $35000 \mathrm{~g}$ for $20 \mathrm{~min}$. and the pellet $\left(\mathrm{F}_{3}\right)$ was suspended in MTN medium. The supernatant was termed $\mathbf{F}_{4}$ and was centrifuged at $92000 \mathrm{~g}$ for $2 \mathrm{hr}$; ; the resulting supernatant was removed and termed $F_{5}$ : in some experiments this supernatant was removed in four layers termed $F_{5}(I)-$ $F_{5}(I V)$, the first being the top fraction and the last being the bottom fraction. The pellet $\left(\mathbf{F}_{6}\right)$ was suspended in MTN medium. Samples were stored at $0^{\circ}$.

Preparation of Tween extract of chloroplasts. Tween 80 was added to chloroplasts $\left(F_{1} a\right)(10 \mathrm{mg}$. of protein $/ \mathrm{ml}$.) to give a final concentration of $0 \cdot 5 \%(v / v)$. The suspension was frozen, kept at $-20^{\circ}$ for a minimum period of $24 \mathrm{hr}$., thawed and then centrifuged at $92000 \mathrm{~g}$ for $3 \mathrm{hr}$. The supernatant was removed and stored at $-20^{\circ}$.

Preparation of purified chloroplasts was carried out by the methods of Eisenstadt \& Brawerman (1964) and Carell \& Kahn (1964).

Preparation of chloroplasts in non-aqueous solvents was carried out by the methods of Stocking (1959) and Smillie (1963).

Adaptation experiments. These experiments were carried out in either the 'resting medium' of Brawerman \& Chargaff (1959) or the heterotrophic growth medium described above. A 21. batch of fully grown culture was harvested, and the cells were washed with $1 \mathrm{~mm}$-potassium phosphate buffer, pH 7.5, and then suspended in $600 \mathrm{ml}$. of sterile adaptation medium. Samples $(80 \mathrm{ml}$.) were removed at intervals. The cells were sedimented, washed with buffer, suspended in $5.0 \mathrm{ml}$. of MTN medium and ultrasonically treated for 2 min. at $0^{\circ}$ in a $50 \mathrm{w}$ MSE ultrasonic power unit. Samples were stored at $-20^{\circ}$ until required.

Effect of inhibitors on adaptation of cells from darkness to light. Growth conditions were as described by Smillie, Graham, Dwyer, Grieve \& Tobin (1967). The cells were harvested at various times and treated as in adaptation experiments.
Chemical determinations. (a) Protein. The method of Lowry, Rosebrough, Farr \& Randall (1951) was used with bovine serum albumin (Armour Pharmaceutical Co. Ltd., Eastbourne, Sussex) as standard.

(b) Chlorophyll. Determinations were carried out by the method of Mackinney as reported by Vishniac (1957). In dark-grown organisms, the small amount of green pigment present is probably protochlorophyll (Schiff \& Epstein, 1965). However, in this work it was extracted from cells and determined exactly as if it were chlorophyll; that is the extinction of the organic solvent extracts was measured at 650 and $665 \mathrm{~m} \mu$ and the content of pigment was determined by using the extinction coefficient for chlorophyll.

Assay of enzymes. (a) Magnesium protoporphyrin $S$ adenosylmethionine methyltransferase (EC 2.1.1.11). This enzyme, referred to below as methylating enzyme, was assayed by the method of Gibson et al. (1963) except that incubations were scaled down to a total volume of $0.25 \mathrm{ml}$. and were carried out at $\mathrm{pH} 7.5$ in $0.1 \mathrm{M}$-tris-HCl buffer. Mercaptoethanol (final concn. $4 \mathrm{~mm}$ ) was added to the assay mixture. The specific radioactivity of the $S$-adenosylmethionine was $0.25 \mathrm{mc} / \mathrm{m}$-mole. Specific activities are expressed as $\mathrm{m} \mu$ moles of monomethyl ester formed $/ \mathrm{hr} . / \mathrm{mg}$. of protein.

Radioactivity was determined as follows. Solutions were plated on $6.25 \mathrm{~cm} .^{2}$ aluminium planchets, dried in air and counted at infinite thinness on a Nuclear-Chicago gas-flow counter with a Micromil end window and operated at the centre of the plateau: $1 \mu$ mole of $S$-adenosyl-[ $\left.M e-{ }^{14} \mathrm{C}\right]$ methionine $(0 \cdot 25 \mu \mathrm{c} / \mu \mathrm{mole})$ gave 175000 counts $/ \mathrm{min}$. under these conditions.

(b) ALA* dehydratase (EC 4.2.1.24). This enzyme was assayed by the method of Burnham \& Lascelles (1963). After incubation the protein was precipitated by the addition of $0 \cdot 1 \mathrm{ml}$. of $25 \%$ (w/v) $\mathrm{CuSO}_{4}, 5 \mathrm{H}_{2} \mathrm{O}$ soln. An equal volume of Ehrlich's reagent was added to the resulting supernatant and the $E_{553}$ value was determined after $5 \mathrm{~min}$. Specific activities are expressed as $m \mu$ moles of porphobilinogen formed $/ 30 \mathrm{~min} . / \mathrm{mg}$. of protein.

Preliminary experiments revealed that the range of protein concentration over which the enzymic activities were linearly proportional to protein varied from fraction to fraction. This range was determined for each fraction.

\section{RESULTS}

Subcellular distribution of enzymes. When pigmented cells of Euglena gracilis were disrupted and the resulting homogenate was incubated with magnesium protoporphyrin and $S$-adenosylmethionine, magnesium protoporphyrin monomethyl ester was formed. After centrifugation of the homogenate at $92000 \mathrm{~g}$ for $2 \mathrm{hr}$., most of the methylating enzyme was recovered in the pellet, but there was a significant amount in the paleyellow supernatant. The distribution of the enzyme in different subcellular structures was determined after suspensions of disrupted cells had been fractionated by the method of Carell \& Kahn (1964). Cells grown autotrophically or heterotrophically in

* Abbreviation: ALA, $\delta$-aminolaevulate. 


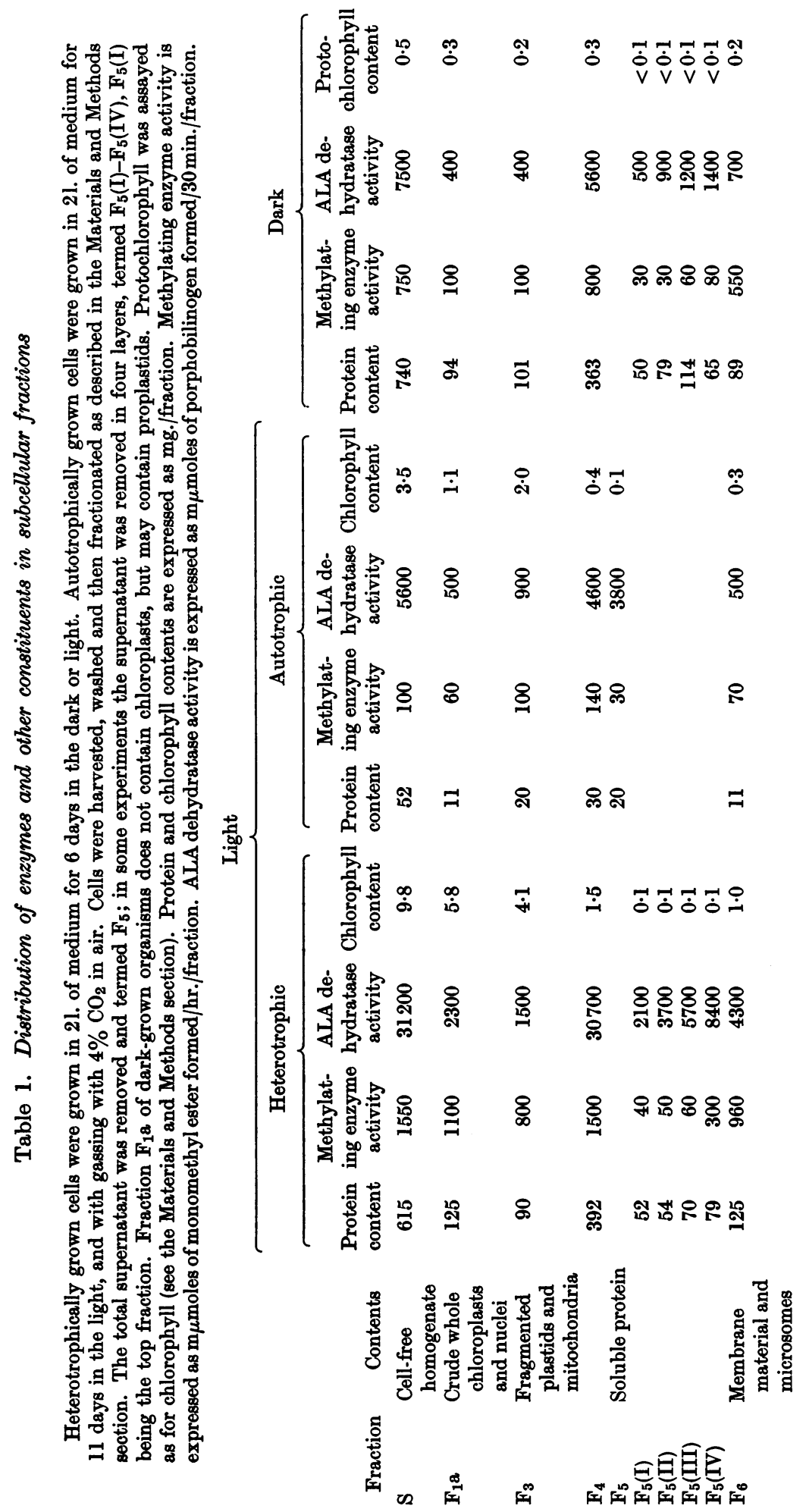


the light and cells grown heterotrophically in the dark were used. The fractions obtained were assayed for protein, chlorophyll and ALA dehydratase activity as well as for methylating enzyme (Table 1). The probable distribution of subcellular structures in the different fractions is indicated in Table 1. This distribution is based on the work of Brawerman \& Chargaff (1959) and Carell \& Kahn (1964); they used similar fractionation techniques but, in addition, examined their fractions for the presence of subcellular structures.

In confirmation of the work of Carell \& Kahn (1964) most of the ALA dehydratase appears to be present in the cytoplasm, but some is bound to particulate material (Table 1). There is a small but significant activity in the various pellet fractions prepared from pigmented and unpigmented cells. Carell \& Kahn (1964) showed that this activity was not removed from the particulate fraction of pigmented cells when crude whole chloroplasts were washed, ultrasonically treated and centrifuged in a density gradient. In crude extracts of autotrophically grown cells, the specific activity of this enzyme/ mg. of protein is twice that found in heterotrophic growth. The specific activity of ALA dehydratase in crude extracts of unpigmented dark-grown cells is very much lower than in pigmented cells: one-fifth of that in cells grown heterotrophically and onetenth of that in cells grown autotrophically.

The methylating enzyme is mainly located in the particulate fractions, although there is some soluble enzyme. In fractions prepared from pigmented cells, the enzyme and the chlorophyll are not distributed in the same manner: thus fraction $\mathbf{F}_{6}$ has a higher enzyme/chlorophyll ratio than has either fraction $F_{1}$ a or fraction $F_{3}$. This suggests either that the enzyme is not present in chloroplasts or that it is not confined to chloroplast material but is also present in other subcellular structures. Pure chloroplasts were prepared in both aqueous and non-aqueous media and both of these preparations contained methylating enzyme and ALA dehydratase. The specific activities of the methylating enzyme in these preparations were respectively $7 \cdot 0$ and $20.0 \mathrm{~m} \mu$ moles of monomethyl ester formed $/ \mathrm{hr}$./ mg. of protein. The methylating enzyme could not be released from the chloroplasts by freezing or by disrupting them by ultrasonic treatment or by osmotic lysis. This indicates that the soluble enzyme does not arise by leaking from the chloroplasts during the fractionation.

Cells grown autotrophically contain four times as much chlorophyll/mg. of protein as those grown heterotrophically. This is probably because autotrophically growing cells make chloroplasts throughout growth and are dependent for their energy source on photosynthesis, whereas heterotrophically grown cells only develop chloroplasts fully towards the

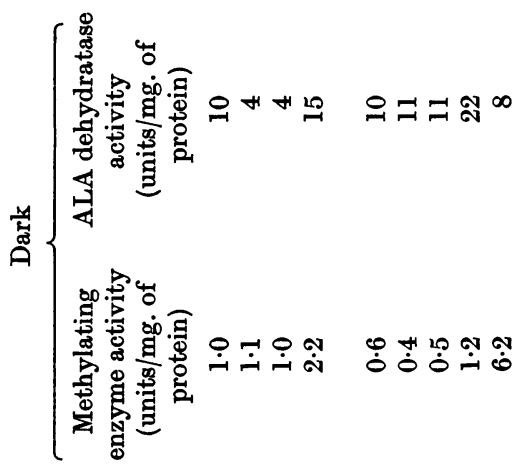

है
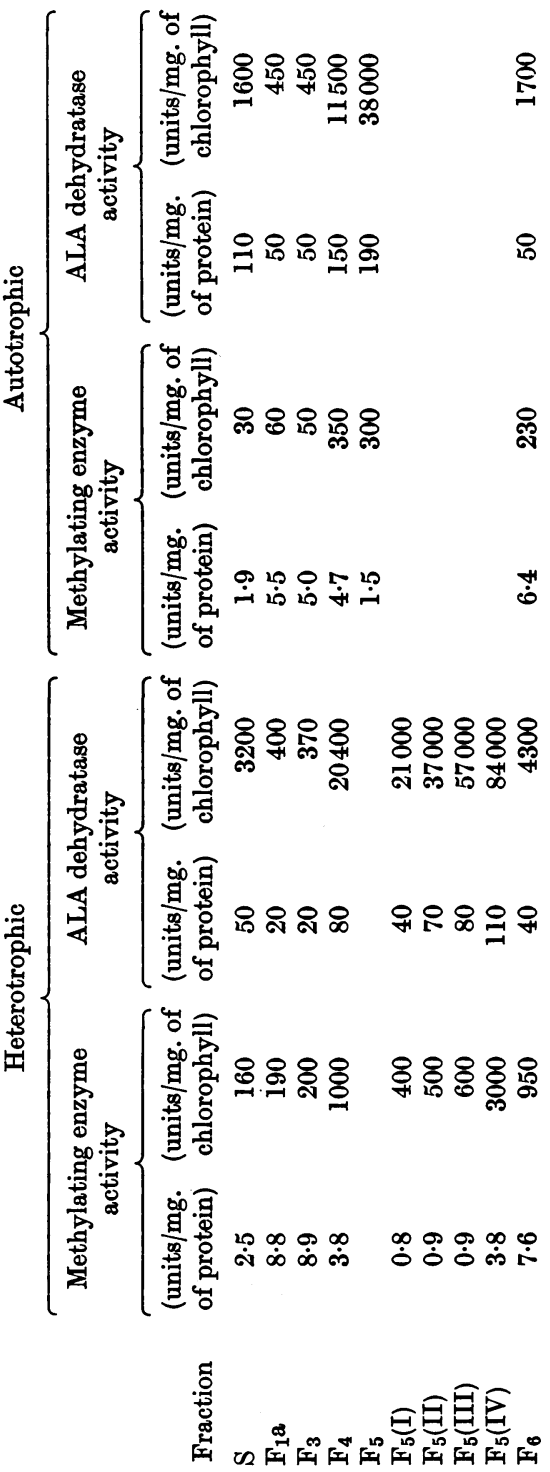
end of the growth phase (Brawerman, 1967). The specific activities of the methylating enzyme in whole homogenates of autotrophically and heterotrophically grown cells are similar (Table 2); in the various particulate fractions the specific activities are also similar, being only slightly higher in heterotrophically grown cells. Thus it appears that the activity of the methylating enzyme is independent of the degree of pigmentation of the cells.

Cells grown in the dark lack chloroplasts; the small amount of pigment present is probably protochlorophyll and this is located in proplastids. These structures are smaller than chloroplasts (Schiff \& Epstein, 1965) and are thought to be more easily disrupted (Brawerman \& Chargaff, 1959). In a cell-free homogenate of dark-grown organisms (S), the specific activity of the methylating enzyme with respect to protein is about half that found in pigmented cells. In extracts of dark-grown cells, the particulate enzyme is mainly found in fraction $F_{6}$; this is in contrast with the findings with extracts of pigmented cells, where particulate enzyme is about equally distributed between all three particulate fractions. This is consistent with the location of the enzyme in proplastids. The specific activity of the methylating enzyme in cells that had been serially subcultured in the dark for 5 weeks was similar to that from cells that had been grown in the dark from a small inoculum of pigmented cells.

Table 1 shows that the sum of the activities of the methylating enzyme in fractions $F_{1} a, F_{3}$ and $\mathbf{F}_{4}$ is greater than in the whole homogenate $(\mathrm{S})$; when pigmented cells were used it was more than twice as great. This may be due to the presence of an inhibitor in crude extracts or to an enzyme that hydrolyses $S$-adenosylmethionine; this has not been investigated further.

Changes of enzyme specific activities on alteration of growth conditions. In previous work (Schiff \& Epstein, 1965) the changes in the cell content of a number of constituents were measured when the growth conditions of a culture of Euglena were altered. When cells growing in the dark are illuminated in fresh medium that is deficient in nitrogen and low in carbon, growth and cell division do not occur, but chlorophyll is formed after a lag (Brawerman \& Chargaff, 1959). The results of a typical experiment are shown in Fig. 1. During the $168 \mathrm{hr}$. of illumination, the total protein did not alter markedly. Chlorophyll synthesis did not occur until $24 \mathrm{hr}$. after the start of illumination and, by $168 \mathrm{hr}$., the content had increased 25 -fold. The methylating enzyme activity doubled. This might have been expected from the enzyme contents of light-grown and dark-grown cells reported in Table 1. The ALA dehydratase activity trebled, but, in contrast with that of the methylating

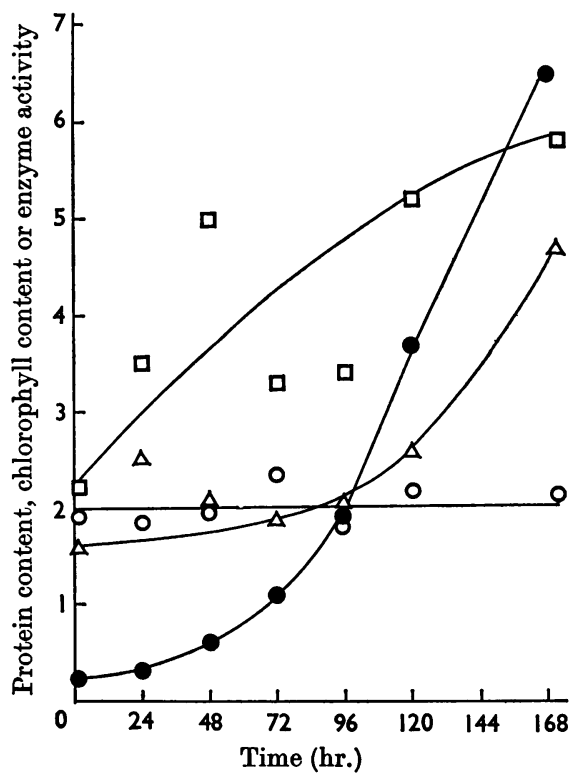

Fig. 1. Adaptation of Euglena from growth in the dark to incubation in the light in resting medium. Cells were grown heterotrophically in the dark, harvested, washed and suspended in resting medium, then placed in the light. O, Protein content, $\mathrm{mg} . / 0 \cdot 1 \mathrm{ml}$. of sample; $\bullet$, chlorophyll content, mg./10ml. of sample; $\triangle$, ALA dehydratase activity, m $\mu$ moles of porphobilinogen formed $/ 30 \mathrm{~min} . / 10 \mu l$. of sample; $\square$, methylating enzyme activity, $m \mu$ moles of monomethyl ester formed $/ \mathrm{hr} . / 50 \mu \mathrm{l}$. of sample.

enzyme, which increased immediately, the ALA dehydratase activity increased slowly initially and the biggest increase was between 120 and $168 \mathrm{hr}$.

When pigmented cells were transferred to resting medium and incubated in the dark (Fig. 2), the cellular protein content was unaltered but that of chlorophyll fell gradually over $168 \mathrm{hr}$. to $56 \%$ of that originally present. The pigment remaining after this time was olive-green and was probably phaeophytin. Schiff \& Epstein (1965) reported the presence of this compound in pigmented Euglena when it was transferred to the dark. The activities of both enzymes tested fell very markedly immediately the cells were transferred to the dark and by $72 \mathrm{hr}$. had reached their lowest values: $25 \%$ and $10 \%$ respectively of the original activities of the methylating enzyme and ALA dehydratase.

When pigmented cells were transferred to growth medium and incubated in the dark (Fig. 3), the loss of chlorophyll was similar to that occurring in resting medium, but, after a lag of about $24 \mathrm{hr}$., the cells started to grow. During the first $48 \mathrm{hr}$. there was a rapid fall in methylating enzyme activity, by $57 \%$, and that of ALA dehydratase fell Bioch. 1969, 111 


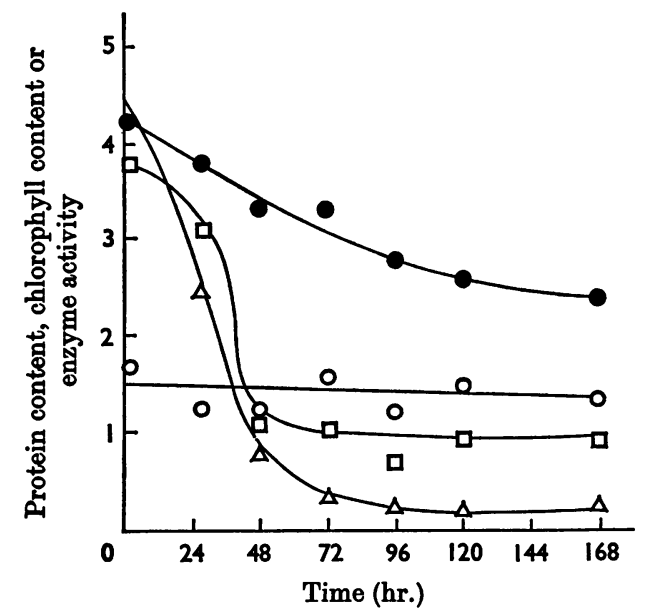

Fig. 2. Adaptation of Euglena from growth in the light to incubation in the dark in resting medium. Cells were grown heterotrophically, harvested, washed and suspended in resting medium, then placed in the dark. O, Protein content, mg. $/ 0.1 \mathrm{ml}$. of sample; $\bullet$, chlorophyll content, mg./10ml. of sample; $\Delta$, ALA dehydratase activity, $\mathrm{m} \mu$ moles of porphobilinogen formed $/ 30 \mathrm{~min} . / 5 \mu \mathrm{l}$. of sample; $\square$, methylating enzyme activity, $m \mu$ moles of monomethyl ester formed $/ \mathrm{hr} . / 20 \mu \mathrm{l}$. of sample.

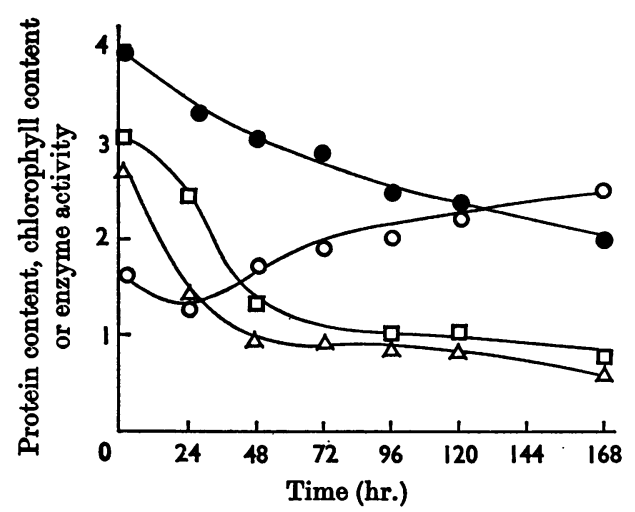

Fig. 3. Adaptation of Euglena from growth in the light to incubation in the dark in growth medium. Cells were grown heterotrophically, harvested, washed and suspended in growth medium, then placed in the dark. $O$, Protein content, mg. $/ 0.1 \mathrm{ml}$. of sample; $\odot$, chlorophyll content, mg./10ml. of sample; $\triangle$, ALA dehydratase activity, m $\mu$ moles of porphobilinogen formed $/ 30 \mathrm{~min} . / 5 \mu \mathrm{l}$. of sample; $\square$, methylating enzyme activity, $m \mu$ moles of monomethyl ester formed/hr./20 $\mu$ l. of sample.

by $64 \%$. In spite of growth of the cells between 48 and $168 \mathrm{hr}$., the activity did not increase again and thus there was a fall in specific activity/mg. of protein throughout this time.

Purification of the methylating enzyme. In spite of the soluble enzyme being only a relatively small proportion of the total in pigmented cells the first attempts at purification were made with this particle-free supernatant. Ammonium sulphate fractionation and protamine sulphate precipitation gave a slight purification. On chromatography of a protamine sulphate supernatant on Sephadex G-200 eluted with 0.01 M-tris-hydrochloric acid buffer (pH 7.5)-4mM-mercaptoethanol, enzyme activity was found to be retarded and was separated from considerable amounts of protein. After this treatment there was a loss of activity when the extract was stored at $4^{\circ}$ or subjected to further procedures. This loss of activity made it difficult to achieve further purification.

The particulate enzyme could not be released in soluble form by ultrasonic treatment of chloroplasts. Acetone-dried powders of whole cells or of chloroplasts were prepared; this powder was active, but there was a loss of activity during the preparation. On extracting the powder with $0.01 \mathrm{M}$-tris-hydrochloric acid buffer, pH 7.5, 70\% of the enzymic activity of the powder was obtained in soluble form. As with the soluble enzyme, purification was hindered by loss of activity of the enzymic material.

When the non-ionic detergent Tween 80 was added to the assay system at a final concentration of $0.5 \%(\mathrm{v} / \mathrm{v})$, both chloroplast and supernatant enzymes showed a twofold increase in expressed activity (Table 3). (This suggested that lipid was involved in the binding of the enzyme to the chloroplast or, alternatively, that the enzyme was a lipoprotein.) When a suspension of chloroplasts in iso-osmotic buffer (MTN medium) was made 0.5\% $(\mathrm{v} / \mathrm{v})$ with respect to Tween, frozen, maintained at $-20^{\circ}$ for $24 \mathrm{hr}$., thawed and centrifuged at $92000 \mathrm{~g}$ for $3 \mathrm{hr} ., 88 \%$ of the activity was found in the supernatant (Table 3). This results in a 12.8-fold increase in specific activity. However, the extract at this stage is still green. This preparation is stable to storage at $-20^{\circ}$ for 1 month and contains $3 \mathrm{mg}$. of protein $/ \mathrm{ml}$. On dilution to $0.1 \mathrm{mg}$. of protein $/ \mathrm{ml}$. the activity is lost quite rapidly, but this loss can be prevented by dilution in the presence of $1 \mathrm{M}$-sodium chloride. Chromatography of the Tween supernatant was performed on a column of Sephadex G-200 equilibrated and eluted with 0.01 M-tris-hydrochloric acid buffer (pH 7.5)-4 mMmercaptoethanol-1 M-sodium chloride. The green material was eluted first, followed by the enzyme. Only $33 \%$ of the activity applied to the column was recovered and the preparation lost all its activity on storage at $4^{\circ}$ for 5 days.

Properties of the methylating enzyme. With the soluble enzyme extracted from chloroplasts by the use of Tween enzyme activity was a linear function of protein concentration up to $0.1 \mathrm{mg}$. of protein per assay and the production of monomethyl ester was 


\section{Table 3. Purification of methylating enzyme}

For experimental details see the text. Specific activity is expressed as $\mathrm{m} \mu$ moles of monomethyl ester formed/ hr./mg. of protein.

Material
Whole homogenate $(S)$
Crude whole chloroplasts $\left(F_{1} a\right)$
Addition of Tween (final concn. $0.5 \%$ )
to chloroplasts
Supernatant from centrifugation of
above at 92000g for $3 \mathrm{hr}$.
Chromatography on Sephadex G-200

Specific
activity
2.54
8.95
18.70

114.0

$174 \cdot 5^{*}$

$\begin{array}{cc}\begin{array}{c}\text { Recovery } \\ \text { (\% of activity in S) }\end{array} & \begin{array}{c}\text { Purification } \\ \text { factor }\end{array} \\ 100 & - \\ 71 & 3.5 \\ 149 & - \\ 131 & 45.0 \\ 43 & 68.7\end{array}$

$68 \cdot 7$

* Most active fraction.

linear for incubation times up to $1 \mathrm{hr}$. The enzyme activity of this extract was similar in tris-hydrochloric acid or phosphate buffers and exhibited a broad $\mathrm{pH}$ optimum at $\mathrm{pH} 8 \cdot 0$. When protoporphyrin was used as substrate, there was a low incorporation of radioactivity into the protoporphyrin fraction; this incorporation was abolished in the presence of 5mm-EDTA in the assay system; this concentration of chelator did not affect the reaction with magnesium protoporphyrin as substrate. In contrast, protoporphyrin was not a substrate when chloroplasts themselves or particlefree supernatant were used.

$K_{m}$ values for magnesium protoporphyrin and $S$-adenosylmethionine were determined by using chloroplasts and soluble enzyme in the presence and absence of Tween in the assay mixture, and Tweenextracted enzyme (Table 4). In some cases difficulty was found in the determination of the $K_{m}$ for magnesium protoporphyrin, as the accuracy of the assay is dependent on the amount of porphyrin isolated and the amount added was necessarily low, so as not to saturate the enzyme. The $K_{m}$ values for magnesium protoporphyrin were similar with all the preparations whereas those for $S$-adenosylmethionine differed considerably. With chloroplasts, the value was low but was seven times higher with the Tween-solubilized enzyme from chloroplasts; passage of this material down a column of Sephadex G-200, which probably removes Tween, lowers the $K_{m}$ to its original value. With the enzyme in particle-free supernatant the $K_{m}$ for $S$-adenosylmethionine was one-quarter of that when Tween was present in the assay.

Effect of inhibitors on enzyme synthesis. It has been found that both mitochondria and chloroplasts contain DNA, RNA and ribosomes and are capable of making at least some of their own proteins (for review see Eisenstadt, 1967).

In addition, it has been found that some inhibitors apparently specifically block protein synthesis either on cytoplasmic or chloroplast ribosomes.
Table 4. $K_{m}$ values for different preparations of methylating enzyme

Sources of various enzyme preparations are described in the text. Where Tween 80 was added to assays with supernatant enzyme the final concentration was $0.5 \%(\nabla / v)$.

\begin{tabular}{|c|c|c|}
\hline Enzyme source & $\begin{array}{l}\text { magnesium } \\
\text { protopor- } \\
\text { phyrin }(M)\end{array}$ & $\begin{array}{l}\text { S-adenosyl- } \\
\text { methionine } \\
\text { (M) }\end{array}$ \\
\hline $\begin{array}{l}\text { Chloroplasts }\left(F_{1} a\right) \\
\text { Enzyme extracted from } \\
\text { chloroplasts with Tween } 80\end{array}$ & $\begin{array}{l}34 \\
15\end{array}$ & $\begin{array}{r}24 \\
160\end{array}$ \\
\hline $\begin{array}{l}\text { Tween 80-extracted enzyme } \\
\text { after chromatography on } \\
\text { Sephadex G-200 }\end{array}$ & 10 & 20 \\
\hline Supernatant enzyme $\left(F_{5}\right)$ & 23 & 79 \\
\hline Supernatant enzyme + Tween 80 & 19 & 21 \\
\hline
\end{tabular}

Working with Euglena, Smillie et al. (1967) found that the synthesis of a number of enzymes located in chloroplasts was inhibited by chloramphenicol but not by cycloheximide, inhibitors that specifically block protein synthesis on chloroplast and cytoplasmic ribosomes respectively. In view of the dual location of both ALA dehydratase and the methylating enzyme, it was decided to investigate the site of synthesis of these enzymes. Experiments were performed as described by Smillie et al. (1967). Euglena, which had been grown in the dark and then starved to deplete endogenous reserves, were illuminated in growth medium in the presence of chloramphenicol $(0.5$ or $1.0 \mathrm{mg} . / \mathrm{ml}$. $)$ or cycloheximide (7 or $15 \mu \mathrm{g} . / \mathrm{ml}$.) or both. At various times samples were taken; protein and chlorophyll contents and enzyme specific activities were determined and compared with those in a control culture illuminated in the absence of inhibitor. A number of experiments were carried out, but it was not possible to obtain completely reproducible results. It was found, in three experiments, that the 
activity of the methylating enzyme, expressed per $\mathrm{ml}$. of culture, increased six- to eight-fold in $72 \mathrm{hr}$. and that in the presence of chloramphenicol there was a three- to four-fold increase; in the presence of cycloheximide there was no increase in activity. The chlorophyll content per $\mathrm{ml}$. of culture increased 22-58-fold in the control and six- to seven-fold in the presence of chloramphenicol; there was no change in chlorophyll content in the presence of cycloheximide. Total protein did not alter either in the controls or in the presence of inhibitors. Thus it would seem that the methylating enzyme is synthesized on cytoplasmic ribosomes. Results on the activity of ALA dehydratase were not clear-cut.

\section{DISCUSSION}

Location and properties of methylating enzyme. In Euglena gracilis a large proportion, but not all, of the enzyme is attached to particulate material. In pigmented Euglena the enzyme appears to be firmly attached to the chloroplast membrane, but comparison of the relative distribution of enzyme and chlorophyll in different fractions may indicate that the enzyme is also located in other subcellular particles. In addition to the enzyme bound to particulate fractions, some of the activity remains in the supernatant after all subcellular particles have been removed by centrifugation. This enzyme appears to be soluble and not attached to small particles since it is retarded on chromatography on Sephadex G-200.

In contrast with the photosynthetic bacterium Rhodopseudomonas spheroides, Euglena does not form chloroplasts or chlorophyll in the absence of light, irrespective of the partial pressure of oxygen, but it does form proplastids and small quantities of protochlorophyll. Proplastids are smaller and thought to be more fragile than chloroplasts. The activity of the methylating enzyme in dark-grown Euglena is as much as half that found in pigmented organisms, and from the distribution in different particulate fractions it would seem to be present in structures that are smaller than chloroplasts and may be proplastids. As in pigmented organisms, a proportion of the enzyme does not appear to be attached to particulate material. It is known (Schiff \& Epstein, 1965) that, when cells containing proplastids are exposed to light, disks and then the chloroplast lamellae are formed from the inner proplastid membrane. In the chloroplast the chlorophyll is entirely, or almost entirely, located in these lamellar regions, and thus it would be reasonable to suggest that the particulate methylating enzyme in etiolated cells is associated with the inner proplastid membrane and will be involved in the synthesis of chlorophyll at or near the site where it is to be laid down.
The significance of the soluble enzyme is more difficult to understand. It is possible that this represents newly synthesized enzyme that has not yet been incorporated into a membrane structure; but it is usually considered that the production of enzyme to be incorporated into membrane proceeds at the same pace as the incorporation itself and thus large excesses of 'soluble' enzyme are avoided. Alternatively, and more probably, it represents enzyme in the course of being incorporated but still only held by weak bonds and thus readily solubilized by the forces employed in cell disruption. The proportion of the enzyme that remains particulate after cell disruption is attached very firmly and is removed only after treatment with detergent, suggesting that it is bound by hydrophobic bonds. The intracellular distribution of many enzymes in Euglena has been studied (Smillie, 1963; see also Hall \& Whatley, 1967) and some are found to have a dual location, but in most cases this can be ascribed to a dual function, e.g. triose phosphate isomerase functions in the carbon reduction cycle of the chloroplast and in the glycolytic pathway of the cytoplasm. However, for the methylating enzyme, there is no known function other than the methylation of magnesium protoporphyrin in chlorophyll synthesis and this seems likely to take place in the chloroplast.

The synthesis of protein in vitro by isolated chloroplasts is inhibited by chloramphenicol but not by cycloheximide (Spencer, 1965; Ellis, 1968). Smillie et al. (1967) found that some of the enzymes involved in photosynthesis, ribulose 1,5-diphosphate carboxylase, NADP-glyceraldehyde 3-phosphate dehydrogenase and fraction I protein, appear to be synthesized on chloroplast ribosomes, i.e. their synthesis was inhibited by chloramphenicol but not by cycloheximide. By contrast, the synthesis of the methylating enzyme is completely inhibited by cycloheximide but only partially inhibited by chloramphenicol, suggesting that it is synthesized by the cytoplasmic ribosome system. The slight inhibition observed in the presence of chloramphenicol may be secondary and due to the disruption of cellular organization as a result of inability to form chloroplasts. Thus it would appear that enzymes in the chloroplast stroma that are involved in the carbon reduction cycle are made on chloroplast ribosomes, whereas the methylating enzyme, which is concerned in the synthesis of chlorophyll, and which is tightly bound to the particulate material of the chloroplast, is made on cytoplasmic ribosomes.

By studying protein synthesis in isolated rat liver mitochondria Roodyn, Suttie \& Work (1962) found that there was no synthesis of specific soluble mitochondrial proteins but that insoluble protein, similar to the mitochondrial structural protein, was 
synthesized. This appears to be the reverse of the situation found in the chloroplasts of Euglena suggested by the present work and that of Smillie et al. (1967). Richardson, Hultin \& Green (1963) isolated a protein preparation from chloroplast lamellae that is thought to have a structural function, but as yet there is no information as to where it is synthesized.

The enzyme solubilized from chloroplasts with Tween 80 has been purified 68-fold as compared with the whole homogenate; the material solubilized by the action of detergent contained much of the chlorophyll of the chloroplast, but this was separated from the enzyme on purification. Studies on the substrate specificity of this preparation indicated that, in Euglena, the sequence of reactions in chlorophyll synthesis is protoporphyrin $\rightarrow$ magnesium protoporphyrin $\rightarrow$ magnesium protoporphyrin monomethyl ester, as was proposed by Gibson et al. (1963) in their work with Rhodopseudomonas spheroides. Radmer \& Bogorad (1967) obtained evidence to support this pathway in Zea mays, and thus it seems that this part of the pathway may be common to all tissues forming chlorophyll or bacteriochlorophyll.

Location of $A L A$ dehydratase. In pigmented Euglena most of the ALA dehydratase is soluble, but a small amount is firmly bound to the chloroplasts (Carell \& Kahn, 1964); this distribution has been confirmed in the present work. In addition it was found that in etiolated Euglena the ALA dehydratase specific activity is markedly lower than in pigmented cells but shows a similar distribution between soluble and particulate fractions.

Carell \& Kahn (1964) also showed that protoporphyrin can be formed in vitro from ALA in both the soluble and chloroplast fractions. The synthesis of protoporphyrin is common to both haem and chlorophyll branches of the biosynthetic pathway, and it might be suggested that the dual location of the enzymes indicates a spatial separation of the synthesis of protoporphyrin for haem production in the soluble fraction from that for chlorophyll production in the chloroplast. ALA dehydratase is the only enzyme in this part of the biosynthetic pathway that has been quantitatively determined, and, although the chlorophyll/haem ratio is high during growth in the light, the chloroplastic/ cytoplasmic ALA dehydratase activity ratio is low. This apparent discrepancy may indicate that the expressed activity of the enzyme in vitro does not correspond to that in vivo or, alternatively, that the biosynthesis of protoporphyrin for the two end products is not distinct and the dual location of the enzyme is, as yet, to be understood.

Changes in enzyme specific activities on alteration of growth conditions. When dark-grown cells were exposed to light in a medium that would not support cell division, the activity of both the methylating enzyme and ALA dehydratase increased markedly. When light-grown cultures were transferred to the dark in either resting medium or growth medium, there was an immediate fall in both enzyme activities and chlorophyll content. In both media, the chlorophyll content and the methylating enzyme activity fell in a similar fashion, but the fall in the dehydratase activity was less marked in growth medium than in resting medium. This may be due to the growing cells' requiring the enzyme for the biosynthesis of haem.

In most systems, it has been thought that ALA synthetase is the rate-controlling enzyme in porphyrin synthesis (Granick \& Urata, 1963; Lascelles, 1964); however, ALA synthetase activity has not yet been demonstrated in extracts of Euglena. Recent work has suggested that ALA dehydratase may limit the rate of porphyrin synthesis in some organisms (Menon \& Shemin, 1967; Muthu Krishnan, Padmanaban \& Sarma, 1968), and the large changes in activity found in Euglena suggest that, in this organism also, its activity may control haem and chlorophyll synthesis.

We thank Professor A. Neuberger for his interest and also the Medical Research Council for finance during part of this work.

\section{REFERENCES}

Baum, S. J., Burnham, B. F. \& Plane, R. A. (1964). Proc. nat. Acad.Sci., Wash., 52, 1439.

Brawerman, G. (1967). In Biochemistry of Chloroplasts, vol. 1, p. 302. Ed. by Goodwin, T. W. New York and London: Academic Press Inc.

Brawerman, G. \& Chargaff, E. (1959). Biochim. biophys. Acta, $31,164$.

Burnham, B. F. \& Lascelles, J. (1963). Biochem. J. 87, 462. Cantoni, G. L. (1957). Biochem. Prep. 5, 58.

Carell, E. F. \& Kahn, J. S. (1964). Arch. Biochem. Biophys. $108,1$.

Eisenstadt, J. M. (1967). In Biochemistry of Chloroplasts, vol. 2, p. 341. Ed. by Goodwin, T. W. New York and London: Academic Press Inc.

Eisenstadt, J. M. \& Brawerman, G. (1964). J. molec. Biol. 10, 392.

Ellis, R. J. (1968). Biochem. J. 110, 42 P.

Gibson, K. D., Neuberger, A. \& Tait, G. H. (1963). Biochem. $J .88,325$.

Gorchein, A., Neuberger, A. \& Tait, G. H. (1967). In Biochemistry of Chloroplasts, vol. 2, p. 411. Ed. by Goodwin, T. W. New York and London: Academic Press Inc.

Granick, S. (1948). J. biol. Chem. 175, 333.

Granick, S. \& Urata, G. (1963). J. biol. Chem. 238, 821.

Grinstein, M. (1947). J. biol. Chem. 167, 515.

Hall, D. O. \& Whatley, F. R. (1967). In Enzyme Cytology, p. 181. Ed. by Roodyn, D. B. New York and London: Academic Press Inc.

Hutner, S. H., Bach, M. K. \& Ross, G. I. M. (1956). J. Protozool. 3, 101. 
Lascelles, J. (1964). Tetrapyrrole Biosynthesis and its Regulation, p. 90. New York: W. A. Benjamin Inc.

Lowry, O. H., Rosebrough, N. J., Farr, A. L. \& Randall, R. J. (1951). J. biol. Chem. 193, 265.

Menon, I. A. \& Shemin, D. (1967). Arch. Biochem. Biophys. 121, 304.

Muthu Krishnan, S., Padmanaban, G. \& Sarma, P. S. (1968). Biochem. biophys. Res. Commun. 31, 333.

Radmer, R. J. \& Bogorad, L. (1967). Plant Physiol. 42, 463.

Richardson, S. H., Hultin, H. O. \& Green, D. E. (1963). Proc. nat. Acad. Sci., Wash., 50, 821.

Roodyn, D. B., Suttie, J. W. \& Work, T. S. (1962). Biochem. J. 83, 29.
Schiff, J. A. \& Epstein, H. T. (1965). In Reproduction: Molecular, Subcellular and Cellular, p. 131. Ed. by Locke, M. New York and London: Academic Press Inc. Smillie, R. M. (1963). Canad. J. Bot. 41, 123.

Smillie, R. M., Graham, D., Dwyer, M. R., Grieve, A. \& Tobin, N. F. (1967). Biochem. biophys. Res. Commun. 28, 604.

Spencer, D. (1965). Arch. Biochem. Biophys. 111, 381.

Stocking, C. R. (1959). Plant Physiol. 84, 56.

Tait, G. H. \& Gibson, K. D. (1961). Biochim. biophys. Acta, 52, 614.

Vishniac, W. (1957). In Methods in Enzymology, vol. 4, p. 342. Ed. by Colowick, S. P. \& Kaplan, N. O. New York and London: Academic Press Inc. 